\title{
Seed Bead Color Patterns from Colonial Period Sites in Texas and Louisiana
}

George Avery

Unknown

Follow this and additional works at: https://scholarworks.sfasu.edu/ita

Part of the American Material Culture Commons, Archaeological Anthropology Commons, Environmental Studies Commons, Other American Studies Commons, Other Arts and Humanities Commons, Other History of Art, Architecture, and Archaeology Commons, and the United States History Commons

Tell us how this article helped you.

This Article is brought to you for free and open access by the Center for Regional Heritage Research at SFA ScholarWorks. It has been accepted for inclusion in Index of Texas Archaeology: Open Access Gray Literature from the Lone Star State by an authorized editor of SFA ScholarWorks. For more information, please contact cdsscholarworks@sfasu.edu. 


\section{Seed Bead Color Patterns from Colonial Period Sites in Texas and Louisiana}

Creative Commons License

(c) (i) (8)

This work is licensed under a Creative Commons Attribution-NonCommercial 4.0 International License 


\title{
Seed Bead Color Patterns from Colonial Period Sites in Texas and Louisiana
}

\author{
George Avery
}

\begin{abstract}
This article focuses on the seed beads recovered from the Spradley site (41NA206), a possible Nacogdoche village site located south of Nacogdochcs, Texas, and compares the seed bead color pattern to that of other colonial period sites in the region, including Deshazo (41NA27), Stephens (41NA202), Pearson (41RA5), Gilbert (41RA13), Roseborough Lake (41BW5), Vinson (41LT1), Womack (4lLR1), 41HO64, Atlanta State Park (41CS37), Ware Acres (41GG31), and the shipwreck of La Belle in Texas; and Los Adaes (16NA16) and Colfax Fcrry (16NA15) in Louisiana. The possible meaning of different seed bead color patterns is bricfly discussed.
\end{abstract}

\section{INTRODUCTION}

Sorting and inventorying 1/16-inch screened material from the Spradley site (41NA206) resulted in the identification of a number of seed beads. Seed beads are glass beads lcss than $4 \mathrm{~mm}$ in diameter which were sewn onto clothing and other personal items. The traditional approach to seed bead analysis is to describe the beads according to recognized bead classification systems, most notably those of $R$. King Harris and Inus Marie Harris (1967), Kenneth E. Kidd and Martha Ann Kidd (1970), and Jeffrey P. Brain (1979). The results of most bead classification reports are used primarily for chronology and bead typc distributions. Few studies have focused on secd bead color patterns-one notablc cxception is J. Gottfred's (1997) work on seed beads from several late $18^{\text {th }}$ century sites in the northwestern United States. This goal of this article is simply to better understand the seed bead color pattern of the Spradley site beads by comparing it to other colonial period sites in Texas and Louisiana. The possible social ramifications of seed bcad color patterns are briefly discussed.

\section{THE SPRADLEY SITE (41NA206)}

The Spradley site (41NA206) is the sitc of a probablc historic period Nacogdoche Indian village habitation roughly three miles south of Nacogdoches. The site was recorded by Tom Middlebrook in 1998, and it is very important as it represents one of the more systematically tested historic period Caddo sites in the area (see Middlebrook 2007). Middlebrook worked at the site in 1998, Jim Corbin directed fieldwork in 2001, and Victor Galan directed the 2003 and 2005 field seasons. The 2005 field season included the excavation of six $3 \times 3 \mathrm{~m}$ units. Six 1 x $1 \mathrm{~m}$ units were water screened through $1 / 16$-inch window screen during the 2005 scason. My involvement with the Spradley site came in the fall of 2006 with the supervising of sorting and inventory of the 2005 water-screened units, which had begun in the summer of 2006. The sorting and inventory continued in the spring of 2007 with students in the Stephen F. Austin Statc University (SFA) Introduction to Archaeology class. SFA student workers finished the sorting and inventory by working in the summer and fall of 2007. All material from the three SFA field seasons at the Spradlcy site is curated at the Dr. Jim Corbin Archaeology Lab at SFA. To date, there have been no published reports of the archaeological investigations of the Spradley site, although several presentations have been made at professional meetings (Galan et al. 2004; Bibby 2006; Galan 2006).

A total of 65 seed beads have been recovered Irom the Spradley site. The colors include whitc, translucent, various shades of blue, green, and red (Figure 1). By the end of spring 2007 it was clear that the seed bead sample from Spradley was different from the secd bead collection from Los Adaes (16NA16), a sample I was most familiar with. Black is the predominant color for seed beads in the Los Adacs collection (Figure 2), and no black seed beads have been recovered from Spradley. This 


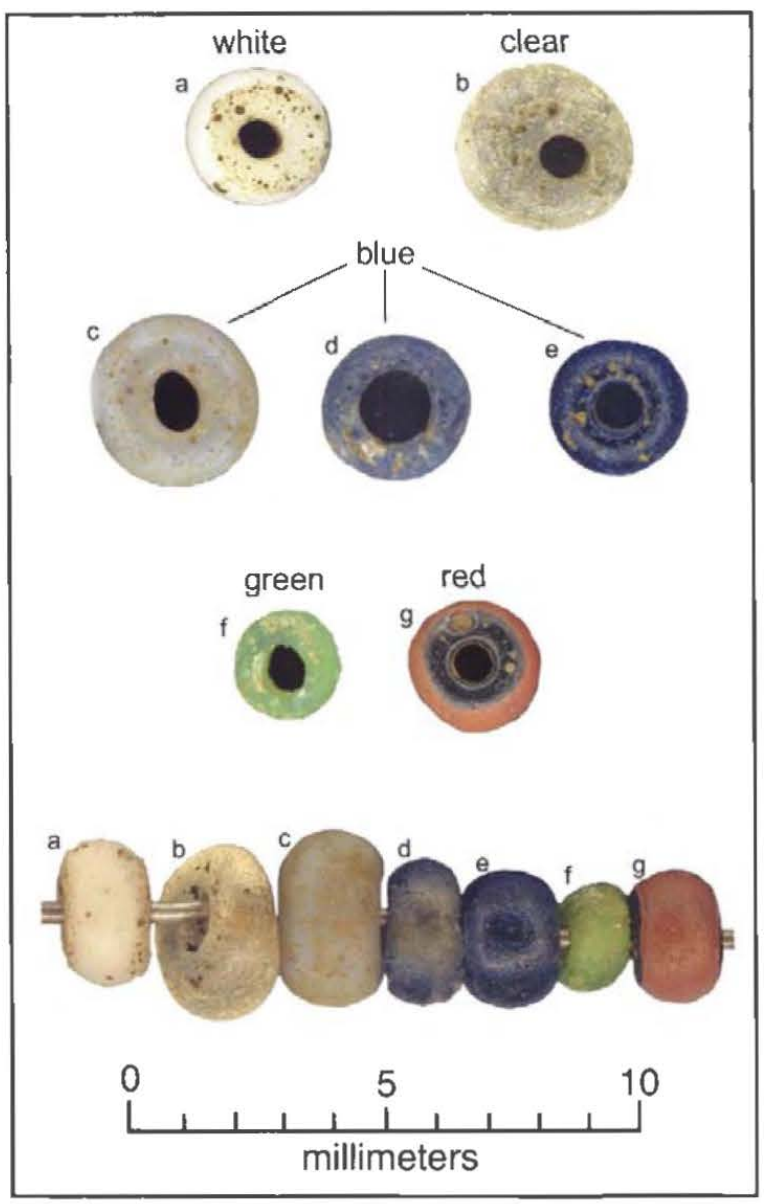

Figure 1. Seed bcads from the Spradley Site (41NA206).

observation led me to focus on color and look at other colonial period sites in Texas and Louisiana to sce if any patterns emerged.

\section{BEAD COLOR PATTERNS FROM COLONIAL PERIOD SITES IN TEXAS AND LOUISIANA}

Figure 3 shows the location of colonial period sites in Texas and Louisiana that have over 100 seed beads in their archaeological assemblages. Table 1 lists these sites, along with the references and bead color proportions. Most of the bead contexts are burials; the beads from Spradlcy, Womack, Gilbert, Vinson, and Los Adaes are not from burials. Bead color in this study is lumped - that is, all the various shadcs of blue are lumped together as simply "blue." There is no distinction made for compound beads in this study. Even though some beads with an overall whitc appearance actually have a clear extcrior layer (e.g., Figure 1a), these beads are lumped with white beads. Also, beads with a red exterior and yellowish core (e.g., Figure 1g) arc described as red. The simplified color categories include white, blue, black, red, clear, green, and ambcr. A pie chart generated in Excel and color-corrected in Adobe Photoshop was made for each site (Figurc 4).

At first glance, several patterns are noticeable. Only Los Adaes and Colfax Fcrry have predominantly black seed beads. White seed beads occur in almost the same proportions at Spradley and Womack, but Spradley has more red, clear, and green beads. Roseborough Lake and Pearson are rcmarkably similar-Gilbert and Vinson are fairly similar, differing primarily in the proportions of red and black beads. Allanta State Park is distinct by its almost total dominance of blue, while Ware Acres is distinct for its total absence of blue. Stephens has substantially higher proportions of green, while Los Adacs has the highest proportion of clear beads.

Jeff Girard was kind enough both to suggest that correspondence analysis would help interpret the variation and also to perform the analysis (Figure 5). The correspondence plot shows that Deshazo, Stephens, Spradlcy, 41HO64, Roseborough Lake, and Pearson are fairly closely related. Surprisingly

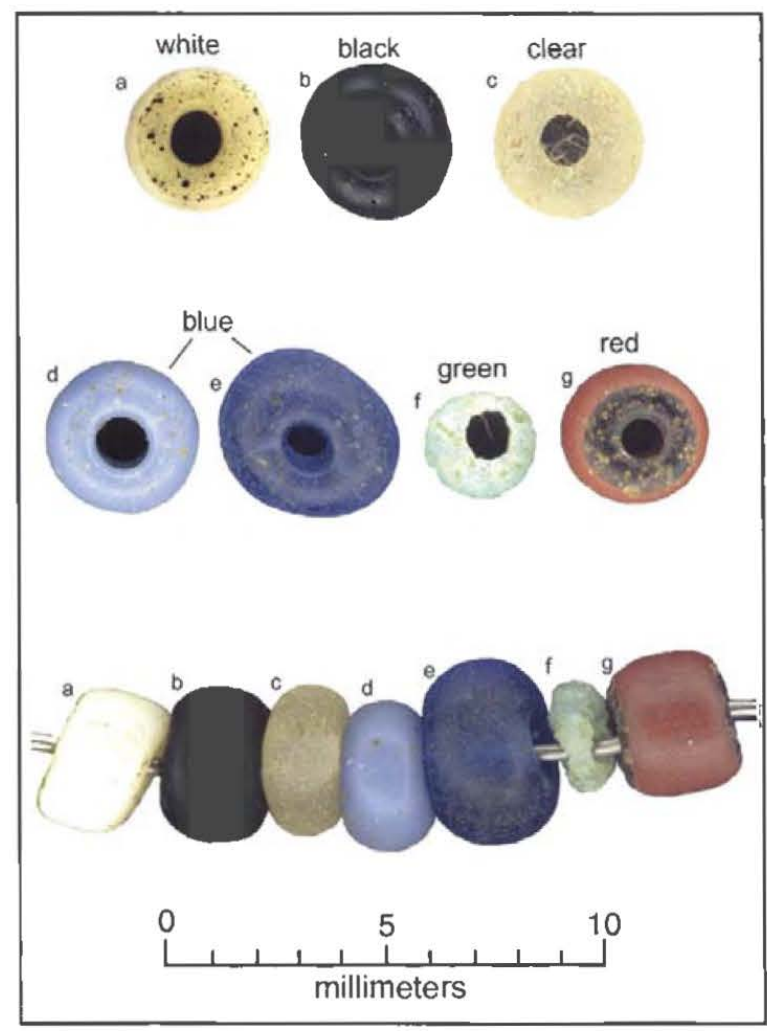

Figure 2. Seed beads from Los Adaes (I6NA16). 


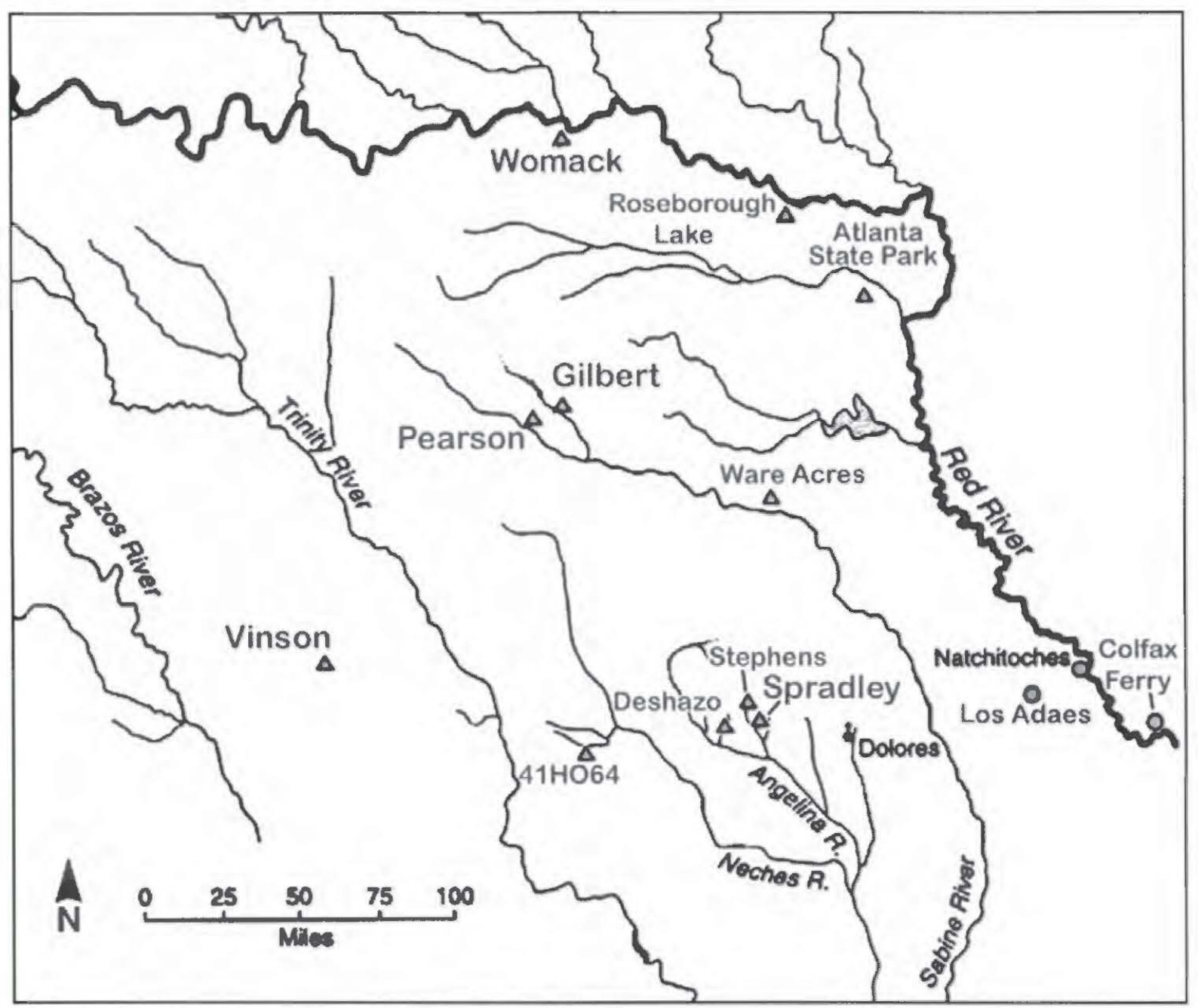

Figure 3. Map showing location of colonial period sites in Texas and Louisiana.

Table 1. Seed Bead Color Totals.

\begin{tabular}{|c|c|c|c|c|c|c|c|c|c|c|}
\hline Site & Date of Occupation & Source & White & Blue & Black & Red & Clear & Green & Amber & Total \\
\hline Spradley (41NA206) & & & 40 & 19 & 0 & 1 & 4 & 1 & 0 & 65 \\
\hline Los Adaes (16NA16) & $1721-1773$ & Avery 2004 & 151 & 278 & 512 & 38 & 144 & 4 & 2 & 1129 \\
\hline Wornack (41LR1) & $1700-1730$ & Hamis et al. 1965 & 760 & 414 & 5 & 8 & 5 & 0 & o) & 1192 \\
\hline Gilbert (41RA13) & $1740-1767$ & Jelks 1967 & 1.209 & 935 & 393 & 388 & 69 & 63 & 22 & 3079 \\
\hline Roseborough Lake (41BW5) & $1720-1780$ & Miroir et al. 1973 & 1,267 & 1,178 & 37 & 125 & 6 & 11 & 8 & 2632 \\
\hline Vinson (41LT1) & $1760-1790$ & Harris et al. 1993 & 1,054 & 632 & 227 & 522 & 48 & 96 & 82 & 2661 \\
\hline Pearson (41RA1) & $1775-1830^{*}$ & Duffield and Jelks 1961 & 782 & 805 & $25+$ & 85 & 5 & 7 & 8 & 1717 \\
\hline $41 \mathrm{HO64}$ & late 1600 s, early 1700 s & Perttula 2004 & 1,172 & 3,698 & 11 & 333 & 0 & 0 & 0 & 5214 \\
\hline DeShazo (41NA27) & $1686-1714$ & Creel 1982 & 339 & 2,675 & 33 & 328 & 0 & 0 & 0 & 3375 \\
\hline Atlanta State Park (41CS37) & pre 1700 & Harris et al. 1980 & 4 & 503 & 2 & 1 & 0 & 0 & 0 & 510 \\
\hline Stephens (41NA202) & $1714-1830$ & Tumer pers. comm. 2008 & 2,067 & 3,267 & 202 & 503 & 73 & 910 & 0 & 7022 \\
\hline Ware Acres (41GG31) & $1700 \mathrm{~s}$ & Jones 1968 & 806 & 2 & 367 & 711 & 0 & 0 & 0 & 1986 \\
\hline Colfax Ferry (16NA15) & $1764-1820$ & Webb and Gregory 1965 & 2,800 & 1.300 & 23,000 & 3,427 & 223 & 0 & 445 & 31,195 \\
\hline La Belle & 1686 & Perttuia pers. comm. 2008 & 247,705 & $32.3,994$ & 201,444 & 402 & 7 & 12848 & 147 & $786,5,47$ \\
\hline
\end{tabular}

enough, Womack and Atlanta State Park are fairly close, and all others are not as closely grouped.

The correspondence plot (see Figure 5) also shows the seed bead color pattern from the wreck of La Belle. Figure 6 shows the seed bead color pattern pie chart for La Belle. The comparison of La Belle color patterns to that of the other sites is most revealing. There are roughly equal amounts of white, blue, and black beads, with very small proportions of green, yellow, and red. The only site that has roughly equal proportions of three bead color is Ware Acres, and this site has 36\% red seed beads-a color that comprises only $0.05 \%$ of the collection of bcads recovered from La Belle (see Table 1). If the 


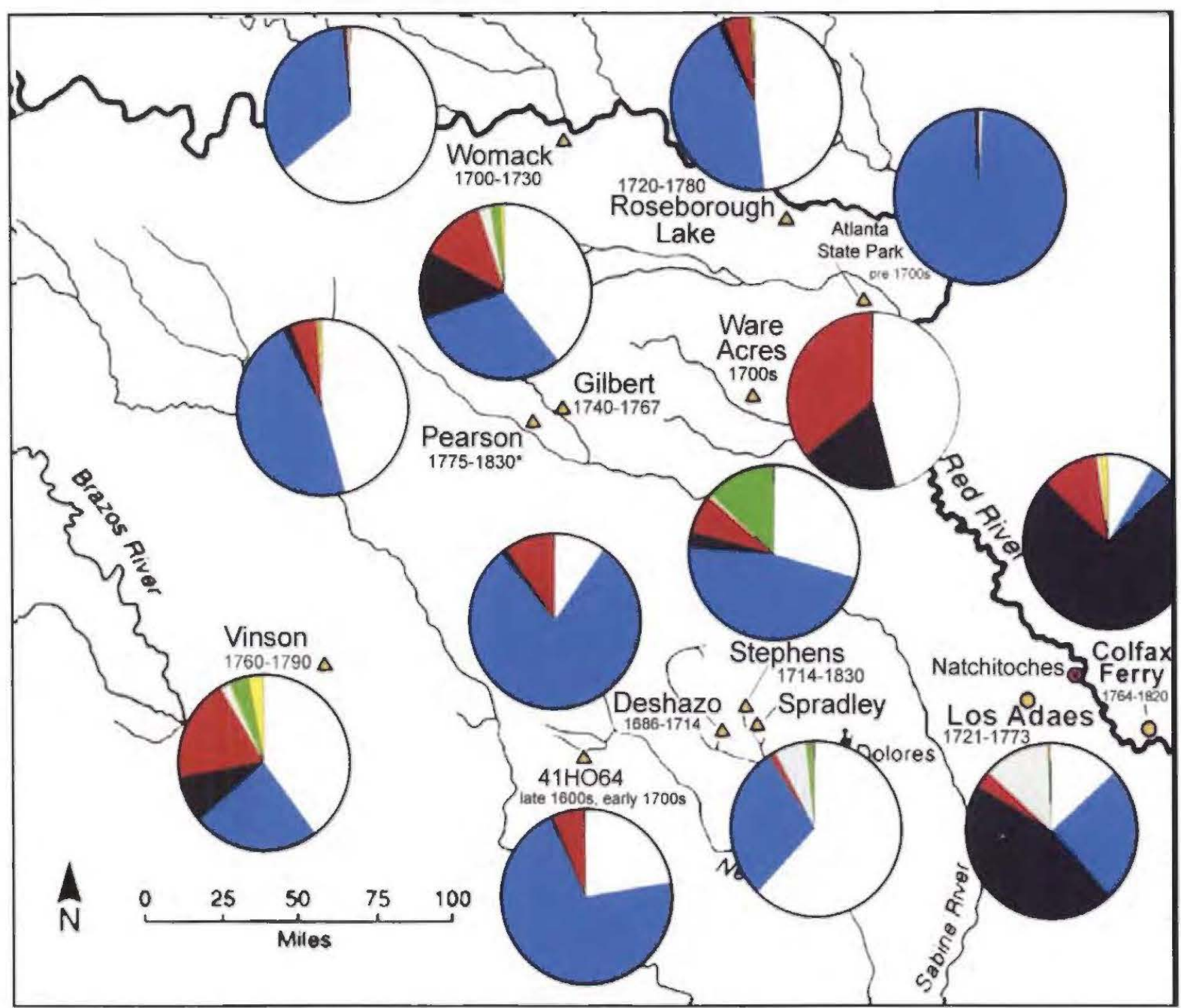

Figure 4. Seed bead color pattern pie charts for colonial period sites in Texas and Louisiana.

bead assemblage from $\mathrm{La}$ Belle represents the bead color proportions available in the late $17^{\text {th }}$ century, then it is clear that late $17^{\text {th }}$ sites in the study sample, including 41HO64, Deshazo, and Atlanta State Park, do not reflect the bead color proportions from $L a$ Belle. Blue is disproportionately represented in all three, and red is disproportionately represented at Deshazo and 41HO64. Therefore, it is clear that the beads are being used in proportions that are being determined by the individual bead workers, and not by the availability.

\section{DISCUSSION}

So what might this all mean? Differences in bead color preference among American Indian groups in North America have been noted, and for some groups-for example, the Plains Indiansthese differences are attributed to ethnic differences (see Stine et al. 1996:57). It is likely that at least one, if not more, of the sites in this study are associated with different tribal groups. Colfax Ferry is a site occupied by Pascagoula and Biloxi Indians, and as both the pie charts and correspondence analysis indicate, Colfax Ferry is very different from most of the other sites in this study. Colfax Ferry is most closely related to the seed bead color pattern for Los Adaes (see Figures 4-5). Womack, Gilbert, Pearson, and Vinson are described as "Norteño" sites in their respective reports, although Tim Perttula (personal communication, 2007) suggests all but Vinson are Caddo sites. The remaining sites-Atlanta State Park, Roseborough Lake, Ware Acres, 41HO64, Deshazo, Stephens, and Spradley — can all be described as Caddo sites. Ware Acres is considered a Caddo 


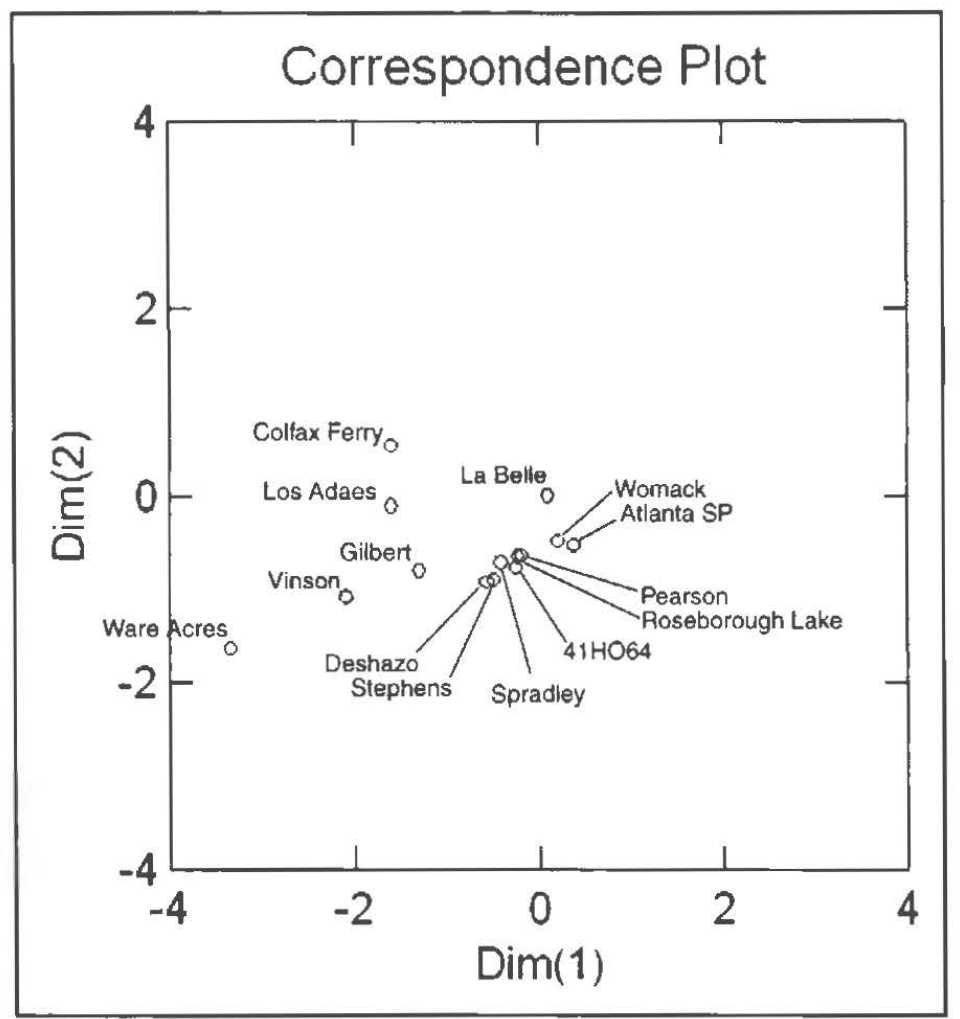

Figure 5. Correspondence analysis for seed bcad color patterns from colonial period sites in Texas and Louisiana. sites, and the less remarkable, but still similar seed bead color patterns for the Gilbert and Vinson sites. It is possible that these four sites represent two groups being in two diffcrent places at different times, instead of four groups being in four different places. That is, given the carlier dates for Roseborough Lake and Gilbert, and later dates for Pearson and Vinson, it is possible that one group left the Gilbert site area prior to 1770 and went to the Vinson site area, and the other group left the Roseborough Lake area prior to 1780 and went to the Pearson site area. However, unpublished observations of gun parts and a religious medallion from Pearson suggest an earlier occupation for the Pearson site (Jay C. Blaine, personal communication 2008). Still, the potential in the future to use seed bead color patterns to track possible movement of individuals or groups through time is an intriguing possibility.

\section{CONCLUSIONS}

any other site in the study.

Clearly, any step in associating bead color pattern with social/political groupings, be they family groups or tribes, should be taken with caution. But, throwing caution to the wind for the moment, it is tempting to hazard an interpretation of the remarkable similarities between the seed bead color pattcrns for the Roseborough Lake and Pcarson

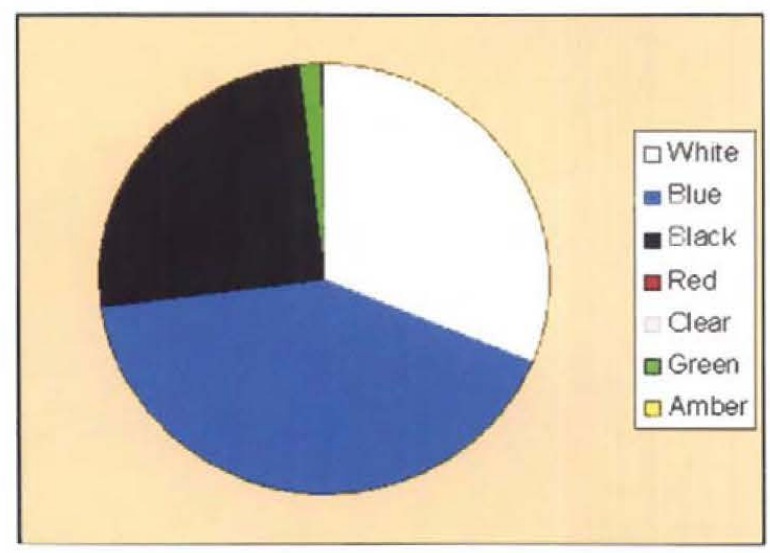

Figure 6. Seed bead color pattern pie chan for La Belle.
The intention of this article is in no way to diminish the importance of meticulous description of glass seed beads. This will always be a eritical part of bead analysis. The goal here was simply to investigate the variation in seed bead color patterns in colonial period sites. This is not a revolutionary idca. Bob Turner, the premier bead analyst in East Texas, mentioned to me that he had thought about it years ago. Seed beads were sewn onto clothing and other personal articles in patterns with varying colors being used. Since different seed bead color patterns have been associated with different social/ political groupings, it is not too much of a leap to suggest that seed bead color patterns from archaeological sites might have potential for providing social/political information about the pcople who wore the beads. Future rescarch might include counting the various colors of seed heads on historic Caddo examples of head work, determining the seed bead color patterns, and comparing this to the seed bead color patterns found on colonial period sites in Texas and Louisiana. 


\section{ACKNOWLEDGEMENTS}

Thanks go to the following SFA students for their efforts in the daunting task of sorting, counting, and weighing the 2005 water-screened samples from the Spradley site: Sara Baker, Emily Borth, Dynna Bullock, Zacheryadam Collins, Jessica Cooley, Carlos Cooper, Heather Cosby, Michael Della Calce, Preston Goodell, Philip Johnson, Joni Luten, Megan Markworth, Katic Mathcnia, Omar Marroquin, Byran McDonald, Will Morgan, Corey Reynolds, Michele Roberts, Christina Stcclc, and David Sims. Karol Chandler-Ezel and Tom Middlebrook supervised the summer 2006 student workersTom developed the sorting template that was used throughout the project in the lab. Bob Turner and Tim Pcrttula provided unpublished information on bead color information from the Stephens site and La Belle. Tim also provided bead color information for the Ware Acres site. Jeff Girard performed the correspondence analysis. Tommy Hailey loaned us the sorting trays from the Cultural Resource Office at Northwestern State University. Special thanks go to Jerry Williams for supporting the activities of the Dr. Jim Corbin Archaeology Lab at SFA.

\section{REFERENCES CITED}

Avery, G.

2004 Annual Report of the Los Adaes Station Archaeology Program. Manuscript on file at the Louisiana Division of Archacology, Baton Rouge, Louisiana.

Bibby, S.

2006 Artifact Distribution at the Spradley Site (41NA206). Presentation given at the $48^{\text {th }}$ Caddo Conference, Nacogdoches, Texas.

Brain, J. P.

1979 Tunica Treasure. Papers of the Peabody Museum of Archacology and Ethnology, Volume 71. Published jointly by The Peabody Museum of Archaeology and Ethnology, Harvard University, Cambridge, Massachusetts, and The Peabody Museum of Salem, Salem, Massachusetts.

Creel, D. G.

1982 Artifacts of Non-Native Manufacture. In The Deshazo Site, Nacogdoches County, Texas, Volume I, edited by D. A. Story, pp. 113-130. Texas Antiquities Permit Series, No. 7. Texas Antiquities Committee, Austin.
Duffield, L. F. and E. B. Jelks

1961 The Pearson Site. A Historic Indian Site at Iron Bridge Reservoir, Rains County, Texas. Anthropology Series, No. 4. Department of Anthropology, The University of Texas, Austin.

Galan, V.

2006 Artifact Analysis for the Spradley Site (41NA206): A Protohistoric Caddo Site. Presentation given at the meeting of the East Texas Caddo Research Group, December 2-3, 2006. Stephen F. Austin State University, Nacogdoches.

Galan, V., S. Wood, C. Meyer, E. Boedy, and B. Chadwick

2004 Artifact Analysis for the Spradley site (41NA206). Presentation given at the annual meeting of the Texas Archeological Society.

Gottfred, J.

1997 Seed Beads in the Northwest. Northwest Journal 4:2-9. http://www.northwestjournal.ca/IV2.htm

Harris, R. K. and I. M. Harris

1967 Trade Beads, Projectile Points, and Knives. In A Pilot Study of Wichita Indian Archeology and Ethnohistory, assembled by R. E. Bell, E. B. Jelks, and W. W. Newcomb, pp. 129-158. Final Report to The National Science Foundation for Grant GS-964.

Harris, R. K., I. M. Harris, J. C. Blaine, and J. Blaine

1965 A Preliminary Archeological and Documentary Study of the Womack Site, Lamar County, Texas. Bulletin of the Texas Archeological Society 36:287363.

Harris, R. K., I. M. Harris, and M. P. Miroir

1980 The Atlanta State Park Site in Northeastern Texas. Louisiana Archaeology 6:231-239.

Harris, I. M., R. K. Harris, and J. E. Smith II

1993 Glass Trade Bcads and Native Made Beads, The Vinson Site (41LT1). Bulletin of the Texas Archeological Society 64:142-147.

Jelks, E. B. (editor)

1967 The Gilbert Site. A Norteño Focus Site in Northeastern Texas. Bulletin of the Texas Archeological Society 37:1-248.

Jones, B. C.

1968 The Kinsloe Focus: A Study of Seven Historic Caddoan Sites in Northeast Texas. Master's thesis, Department of Anthropology, University of Oklahoma, Norman.

Kidd, K. E. and M. A. Kidd

1970 A Classification System for Glass Beads for the Use of Field Archaeologists. Canadian Historic Sites: Occasional Papers in Archaeology and History- 
No. 1, pp. 45-89. National Historic Sites Service, National and Historic Parks Branch, Department of Indian Affairs and Northern Development, Ottawa.

Middlebrook, T.

2007 Survey of Historic Caddo Sites in Nacogdoches County. Journal of Northeast Texas Archaeology 26:95-115.

Miroir, M. P., R. K. Harris, J. C. Blaine, and J. McVay

1973 Bénard de la Harpe and the Nassonite Post. Bulletin of the Texas Archeological Society 44:113-167.
Perttula, T. K.

200441 HO64/41HO65, Late $17^{\text {th }}$ to Early $18^{\text {th }}$ Century Caddo Sites on San Pedro Creek in Houston County, Texas. Bulletin of the Texas Archeological Society 75:85-103.

Stine, L. F., M. A. Cabak, and M. D. Groover

1996 Blue Beads as African-American Cultural Symbols. Historical Archaeology 30(3):49-75.

Webb, C. H. and H. F. Gregory

1965 European Trade Beads from Six Sites in Natchitoches Parish, Louisiana. The Florida Anthropologist $18(3): 15-44$. 


\section{โ ว.กద!}

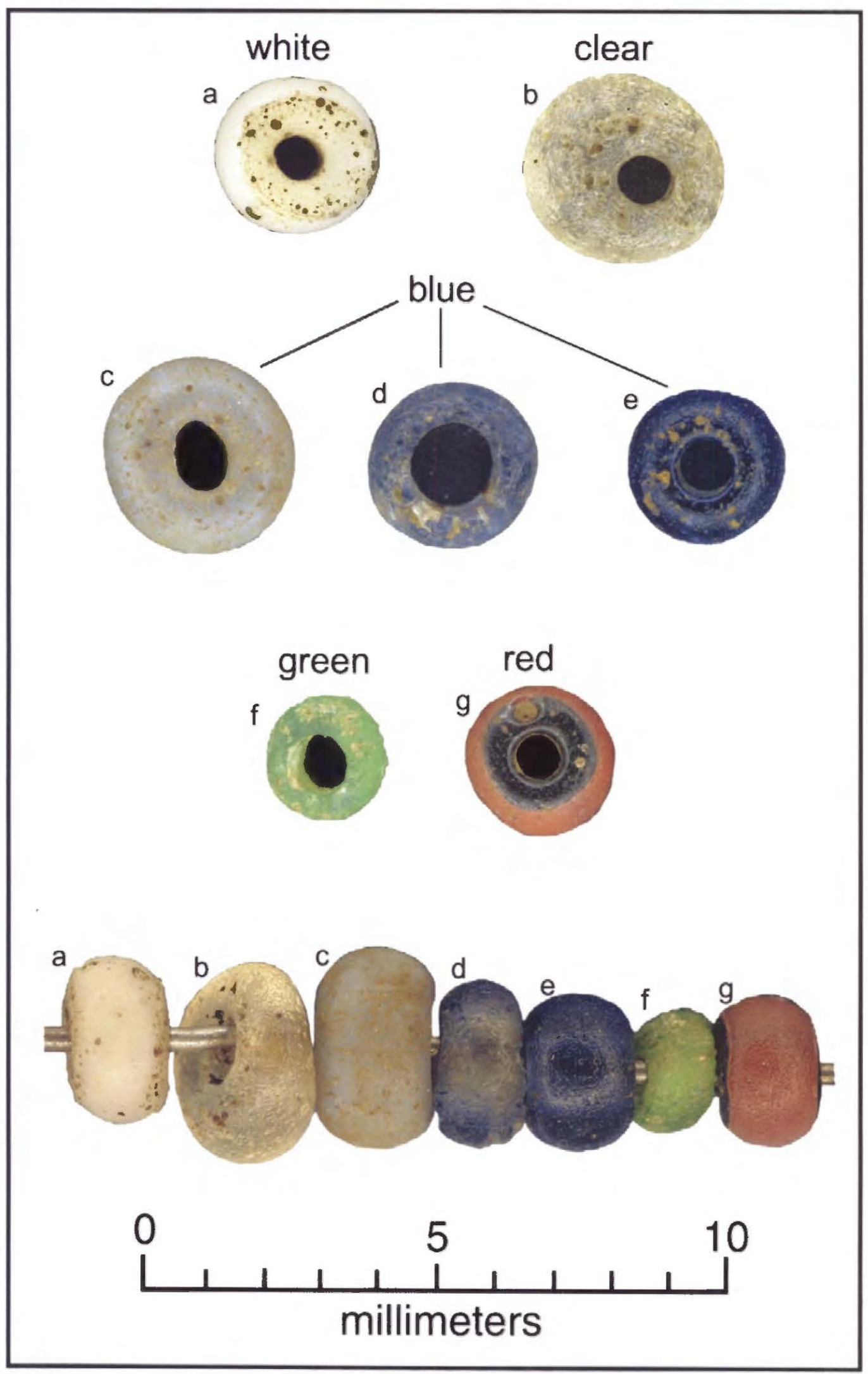




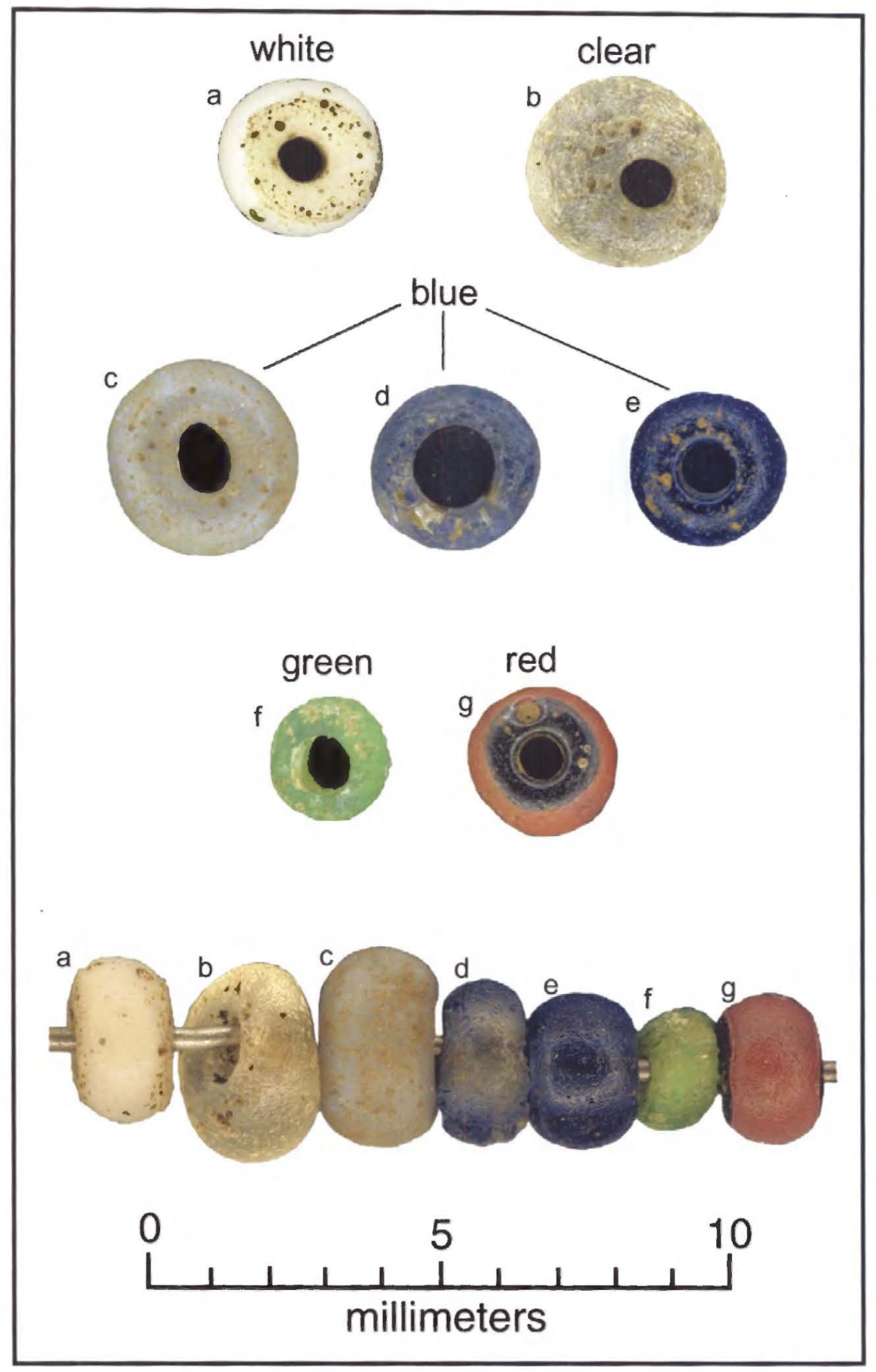

Figure 2 


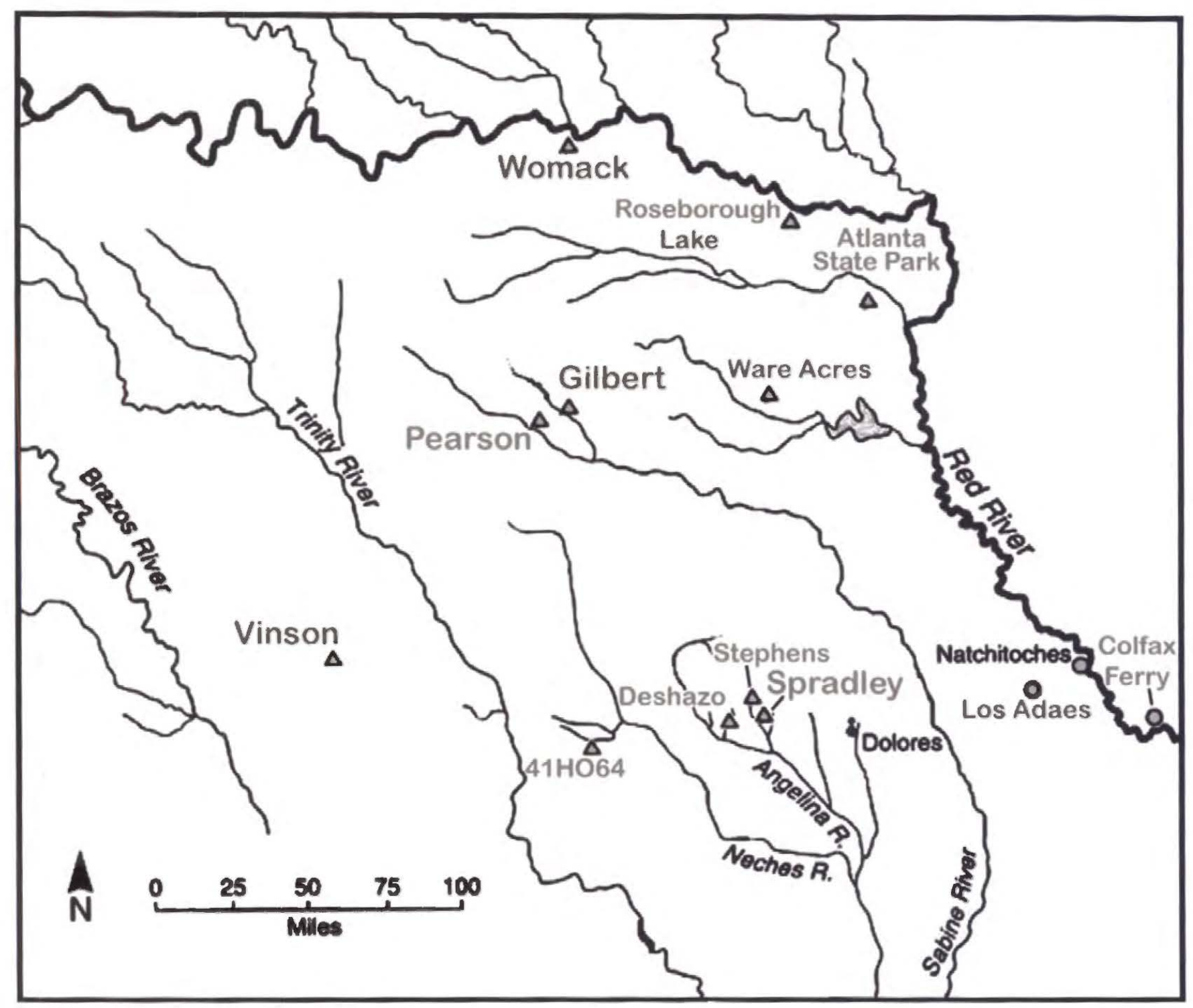

Figure 3 


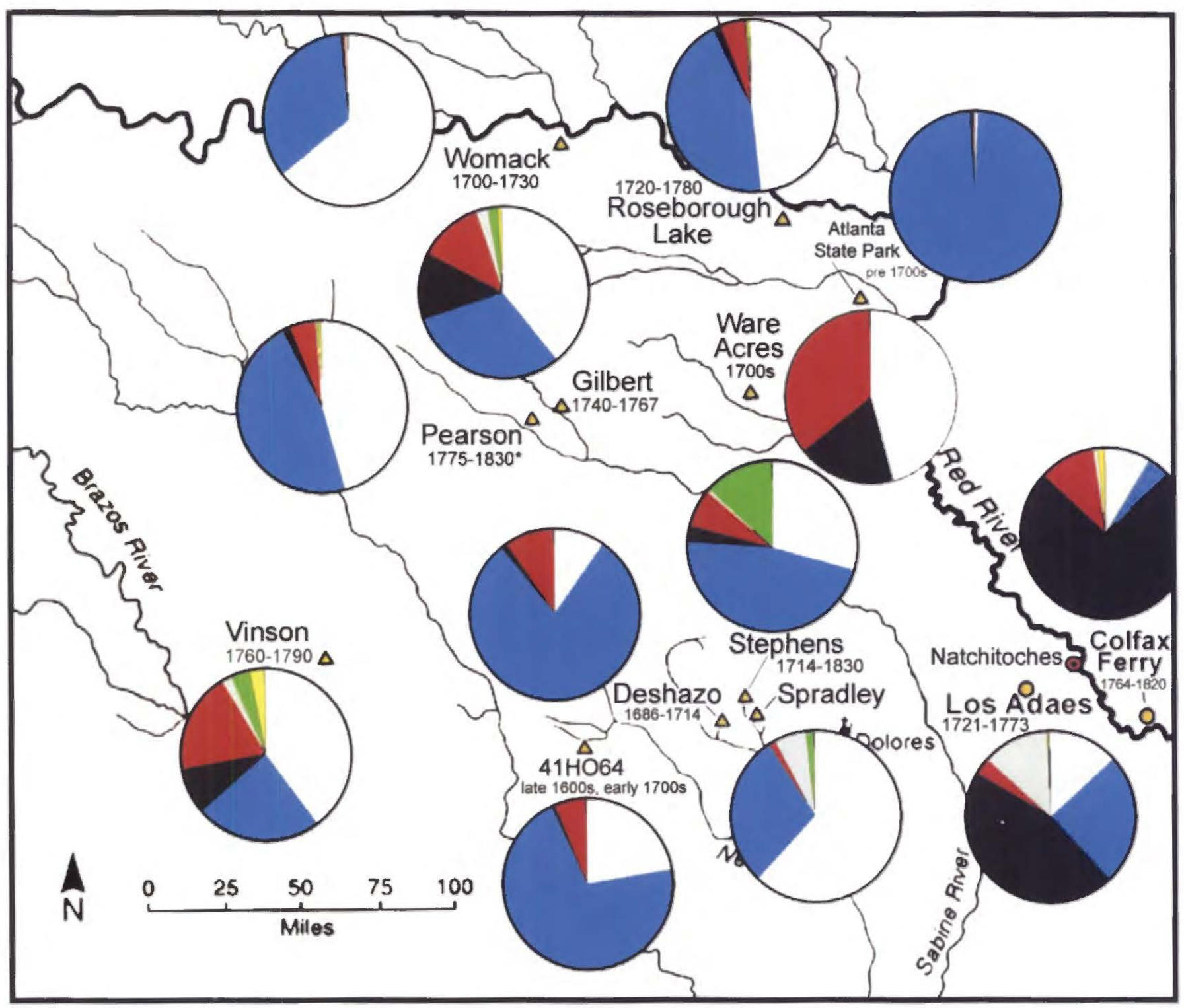

Figure 4 


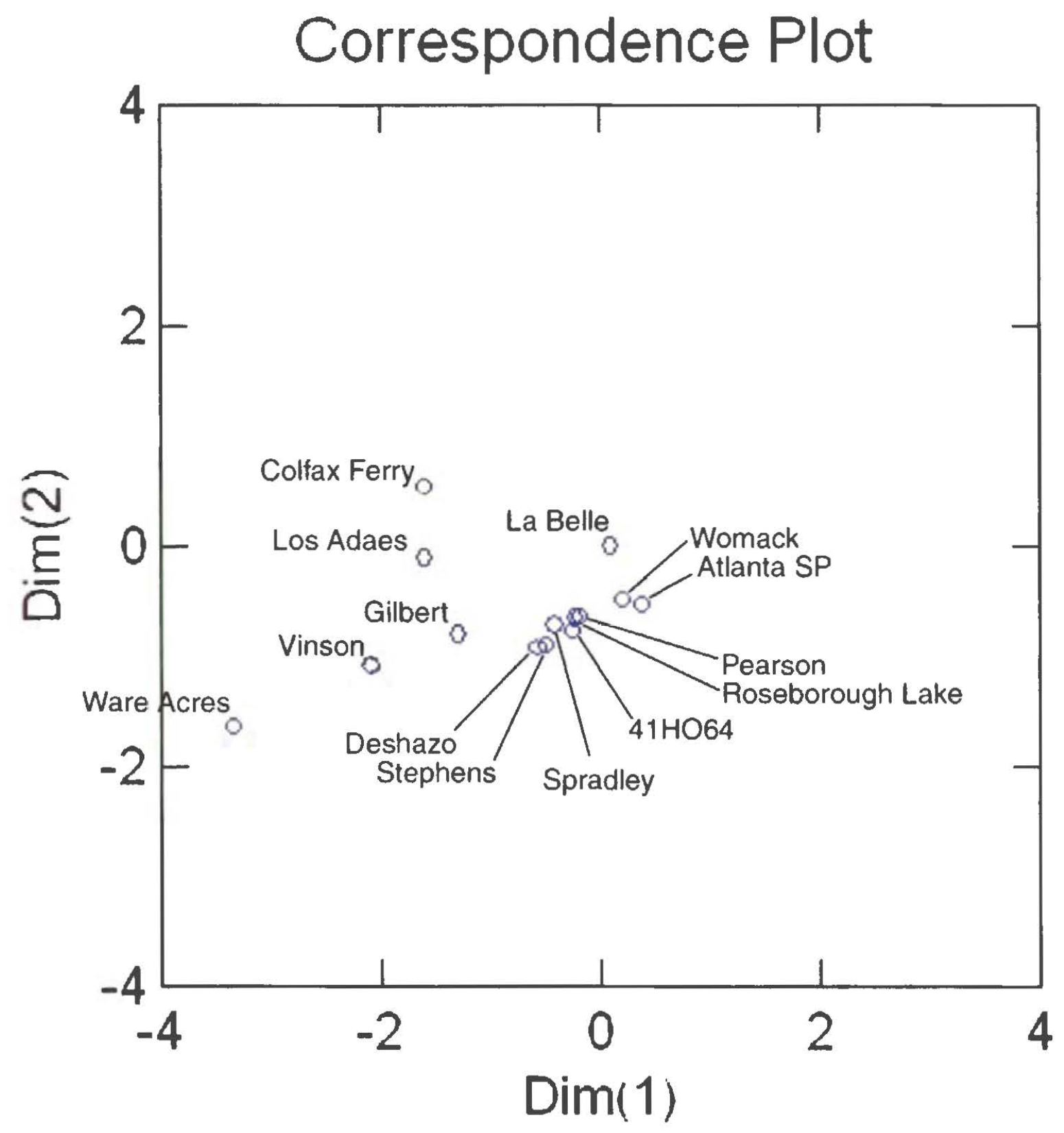

Figure 5 


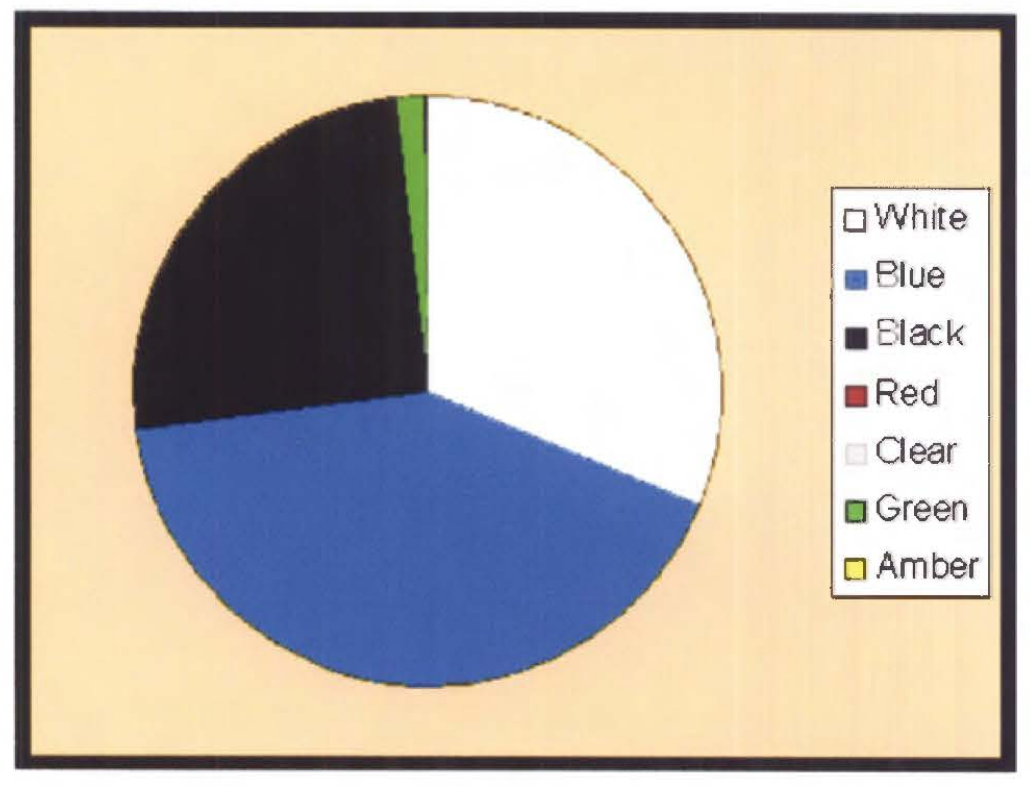

Figure 6 